\title{
Examining the role of terrestrial lichen transplants in restoring woodland caribou winter habitat
}

\author{
by Sean B. Rapai ${ }^{1, *}$, Duncan McColl² and Richard Troy McMullin ${ }^{3}$
}

\begin{abstract}
The development of habitat restoration techniques for restoring critical woodland caribou (Rangifer tarandus caribou) winter habitat will play an important role in meeting the management thresholds in woodland caribou recovery plans. The goal is to restore disturbed environments within critical winter habitat for the declining woodland caribou. Woodland caribou are diet specialists, utilizing lichen-rich habitat for forage during winter months. Cladonia sub-genus Cladina is the most frequently eaten species during this time. Herein, we provide: 1) A review of previously used methods for transplanting Cladonia sub-genus Cladina and their feasibility in restoring woodland caribou winter habitat; 2) A stepby-step protocol on how to carry out a terrestrial lichen transplant program (using Cladonia sub-genus Cladina and C. uncialis); and, 3) An evaluation of our protocol through the establishment of a case study in northern British Columbia. Our results indicate that transplanting $C$. sub-genus Cladina fragments is the most efficient technique for transplanting terrestrial lichen communities, but transplanting lichen 'patches' or 'mats' may also be effective.
\end{abstract}

Key words: Cladonia, Cladina, reindeer lichen, restoration, winter habitat

\section{RÉSUMÉ}

La mise au point de techniques de réhabilitation pour restaurer l'habitat vital d'hiver essentiel du caribou forestier (Rangifer tarandus caribou) jouera un rôle important pour latteinte des seuils d’aménagement dans les plans de rétablissement du caribou forestier. Il s’agit en fait de restaurer les environnements perturbés dans les domaines vitaux pour la caribou forestier dont la population est en déclin. Le caribou forestier a une diète spécifique et compter sur les habitats riches en lichen pour s'alimenter durant les mois d'hiver. C'est principalement la Cladonia du sous-genre Cladina dont il se nourrit durant cette période. Dans cet article, nous proposons: 1) Une analyse des méthodes utilisée précédemment pour transplanter la Cladonia du sous-genre Cladina et leur potentiel pour restaurer l'habitat d'hivernement du caribou forestier; 2) Un protocole détaillé pour réaliser un programme terrestre de transplantation (avec la Cladonia du sous-genre Cladina et C. uncialis); et, 3) Une évaluation de notre protocole au moyen d'une étude de cas que nous avons réalisée dans le nord de la Colombie-Britannique. Nos résultats indiquent que la façon la plus efficace pour transplanter des communautés de lichens terrestres consiste à transplanter des fragments de $C$. sous-genre Cladina, mais quon peut aussi la transplanter sous forme de «talles» (patches) ou de "plaques»" (mats).

Mots-clés: Cladonia, Cladina, lichen des caribous, restauration, habitat d'hivernage

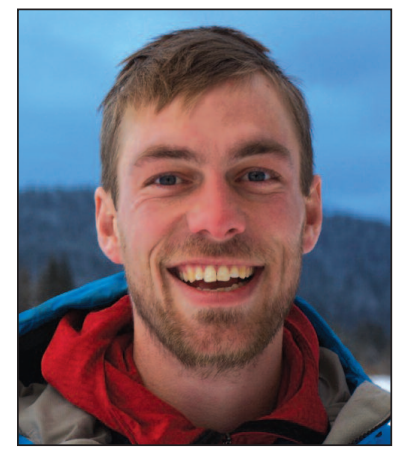

Sean B. Rapai

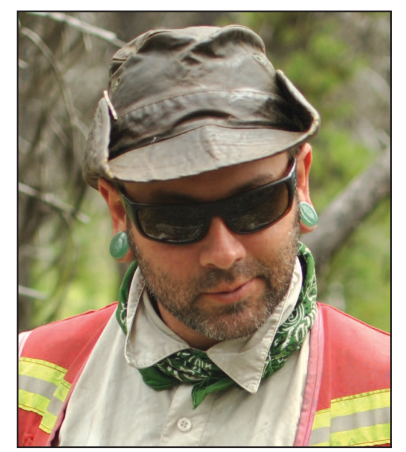

Duncan McColl

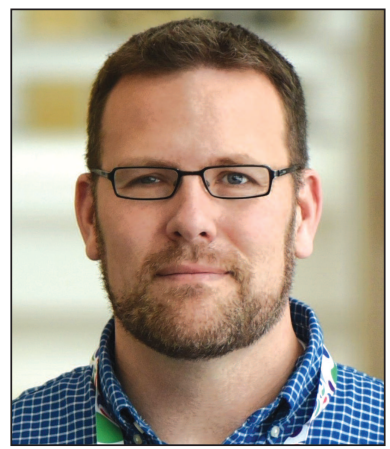

Richard Troy McMullin

\footnotetext{
${ }^{1}$ Chu Cho Environmental, $19403^{\text {rd }}$ Avenue, Prince George, British Columbia, Canada. V2M 1G7; *corresponding author: sean.rapai@gmail.com

${ }^{2}$ British Columbia Ministry of Forests, Lands and Natural Resource Operations and Rural Development. 2000 South Ospika Boulevard, Prince George, British Columbia Canada. V2N 4W5

${ }^{3}$ Canadian Museum of Nature, PO Box 3443 Stn "D”, Ottawa, Ontario, Canada. K1P 6P4
} 


\section{Introduction}

Historically, the Canadian woodland caribou (Rangifer tarandus caribou Gmelin) range included the Acadian and boreal forests and mountains from Newfoundland to Haida Gwaii (Festa-Bianchet et al. 2011). Populations across the country, however, have declined dramatically in recent years (FestaBianchet et al. 2011, COSEWIC 2014a, 2014b). The declines have been more perilous for some regional populations such as the Atlantic-Gaspésie boreal population, as well as the southern and central mountain caribou in British Columbia, which were all recently listed as 'Endangered' by the Committee on the Status of Endangered Wildlife in Canada (COSEWIC 2014a, 2014b). Conservation efforts to date have been inadequate at reversing this trend (Festa-Bianchet $e$ t al. 2011).

Woodland caribou have been split into three population units in British Columbia: northern mountain, central mountain, and southern mountain, based on habitat use and behavior (COSEWIC 2011). Southern mountain caribou were listed on Schedule 1 of the Federal Species at Risk Act (SARA) as 'Threatened', with northern mountain caribou listed as of 'Special Concern' in 2002. Changes in ecotype boundaries have altered some herd population unit designations, and led to the creation of a central mountain population unit. COSEWIC (2014a) assessment recommends 'Special Concern' listing for the northern mountain population, with the central and southern mountain populations listed as 'Threatened'.

The causes of decline are multifaceted, vary by region, and there is uncertainty about the extent these declines can be attributed to human influence (Festa-Bianchet et al. 2011). Predation is a well-understood cause of caribou mortality (Seip 1992, Schaefer et al. 1999, Environment Canada 2012). Whereas the influence of habitat alteration (McLoughlin et al. 2003, Vors et al. 2007, Environment Canada 2012), changed predator-prey dynamics (Seip 1992, Vors et al. 2007, Boreal Caribou Aboriginal Traditional Knowledge - Aseniwuche Winewak Nation 2010, Wittmer et al. 2010), linear features (James and Stuart-Smith 2000, Government of Alberta 2016, Pigeon et al. 2016), and changes in forest structure due to mountain pine beetle infestations and/or associated salvage logging (Williston and Cichowski 2004, Cichowski and Haeussler 2013) are more complex. It has become clear that unsustainable predation throughout the Canadian range of woodland caribou is facilitated by habitat change and altered predator-prey dynamics (Seip 1992, Festa-Bianchet et al. 2011, Environment Canada 2012).

Caribou are diet specialists, utilizing lichen-rich habitat for forage during winter months (Cichhowski 1993, Dzus 2001, Newmaster et al. 2013). This is the time of year when food is most limited and environmental conditions are most difficult. However, the diet of caribou is more varied throughout the spring, summer and fall, as deciduous shrubs, graminoids and forbs become common forage (Thompson et al. 2015, Denryter et al. 2017). Critical low elevation winter habitat typically displays an open pine (Pinus spp.) and spruce (Picea spp.) canopy, has poorly developed herbaceous and shrub cover, with an abundance of lichen mats of Cladonia uncialis and C. sub-genus Cladina in the understory. The sub-genus Cladina excludes Cladonia uncialis, but includes four terres- trial lichen species (Cladonia mitis, C. rangiferina, C. stellaris, and C. stygia) that are the most frequently eaten species in the winter months by woodland caribou in Canada (Environment Canada 2012, Newmaster et al. 2013, B.C. Conservation Data Centre 2016a). Similar to C. uncialis, the Cladonia subgenus Cladina are most often found in coarse, well-drained and nutrient poor soils (Brodo et al. 2001). Some subpopulations of woodland caribou also utilize Stereocaulon spp., Cladonia gracilis subsp. turbinata, and arboreal lichen species (i.e., Bryoria spp.) for forage (Cichowski 1993, Newmaster et al. 2013, B.C. Conservation Data Centre 2016b).

In the boreal caribou recovery plan, $65 \%$ undisturbed habitat outside of core habitats, is identified as the disturbance management threshold (Environment Canada 2012). A key element of the strategy is to i) maintain $65 \%$ habitat and/or ii) restore disturbed habitat to a minimum of $65 \%$ undisturbed habitat (Environment Canada 2012); this threshold has been incorporated in the Recovery Strategy for the Woodland Caribou, southern mountain population, with $0 \%$ disturbance in critical habitats (Environment Canada 2014). The development of habitat restoration techniques for restoring critical winter caribou habitat will play an important role in meeting the management thresholds established in the woodland caribou recovery plan (Environment Canada 2014), and for mitigating and restoring disturbed environments within critical winter habitat for all populations of woodland caribou in Canada. A pattern of habitat loss, altered predator-prey dynamics and population fragmentation has been observed within the central and southern mountain caribou, as well as the Atlantic-Gaspésie boreal population (COSEWIC 2014a, 2014b). Without effective habitat restoration strategies, the continued loss and alteration of critical habitat will contribute to the decline of woodland caribou across Canada.

Techniques for restoring caribou winter habitat have focused on transplanting terrestrial lichen, specifically $C$. subgenus Cladina (Duncan 2015). Cladonia sub-genus Cladina propagates through thallus fragmentation which is an asexual mode of reproduction. Fragments are distributed naturally by wind, water and animals (Goward 2000, Brodo et al. 2001), and most often fall within one metre of the colony (Heinken 1999, Roturier et al. 2007). In instances where there is a large disturbance footprint, and no lichen propagules are present, lichen establishment is dispersal-limited. Terrestrial lichen transplanting techniques have been examined in a variety of landscapes from red-stemmed feathermoss colonies (Cichowski et al. 2008), re-generating second growth forests (Roturier et al. 2007, Roturier and Bergsten 2009, Duncan 2011), handfelled and partial cut forest (Enns 1998), to quarries (Campeau 2013), mine overburden (Rapai et al. 2016), aggregate mines (Hugron et al. 2013), and other industrial disturbances (Turner et al. study in Duncan 2015).

Several studies have shown that transplanting C. subgenus Cladina fragments is the most efficient and promising technique for restoring terrestrial lichen communities (Roturier et al. 2007, Roturier and Bergsten 2009, Duncan 2011, 2015). However, in the absence of active grazing, transplanting lichen 'patches' or 'mats' may also be effective (Enns 1998, Roturier and Bergsten 2009), albeit less efficient and more costly in terms of labour and impacts on collection sites (Duncan 2011, 2015). Organic amendments with materials 
such as peat (Hugron 2013), straw (Campeau 2013, Hugron 2013), bark and twigs (Roturier et al. 2007) have also been found to increase lichen cover. Duncan (2015) suggests that appropriate substrate preparation may increase lichen propagule retention and allow for appropriate wetting and drying cycles. Lichen growth is based on the amount of time lichen receive light while wet (Nash 2008), and so treatments that enhance moisture could have a benefit to lichen growth. The results of these studies indicate that the artificial dispersal and transplanting of lichen fragments and mats is the most promising technique available for restoring terrestrial lichen communities. However, there are still questions surrounding the operational feasibility, the influence of substrate, sustainable propagule sources, and whether lichen fragments or mats represent the more favourable method of dispersal (Duncan 2015).

Based on an extensive literature review on terrestrial lichen restoration, we illustrate and evaluate the methods necessary to transplant lichen fragments and mats by hand in a post wildfire forest environment. The case study presented has allowed us to address limitations and implementation challenges for this method.

\section{A Review, Case Study, and Recommended Proce- dures for Establishing a Terrestrial Lichen Restora- tion Project}

In the summer of 2014, two large-scale wildfires burned through the habitat of the Chase and Finlay herds of the northern mountain caribou within the traditional territory of the Tsay Keh Dene Nation in British Columbia, Canada. Several of the areas burned had been identified as low elevation winter ranges, post rut aggregation, high elevation winter range and migration corridors by the British Columbia Ministry of Forests, Lands and Natural Resource Operations and Rural Development. Historically, caribou shift their use of habitat from burned areas into more suitable areas, a strategy that is based on the availability of alternative undisturbed habitat (Environment Canada 2012). Despite being a natural component of the boreal ecosystem, when combined with human caused habitat disturbance, forest fires can threaten the recovery of caribou (Environment Canada 2012). The goal of our project is to accelerate the return of the burned area to productive caribou winter habitat.

Post-fire lichen succession follows a fairly predictable timeline with a return to high quality caribou forage after 40-70 years (Maikawa and Kershaw 1976, Carroll and Bliss 1982, Thomas et al. 1996, Dunford et al. 2006). Post-fire lichen succession in the boreal forest typically starts with Cladonia mitis, then C. rangiferina, and lastly C. stellaris (Ahti 1959, 1961; Maikawa and Kershaw 1976, Morneau and Payette 1989, Webb 1998). However, timelines may vary.

Many Cladonia spp. (Cladonia gracilis, C. mitis, and various 'cupped' species) can return to sites within 11-50 years, while species such as Cladonia rangiferina, C. stellaris and C. uncialis take an estimated 51-120 years to return to burned areas of northern Saskatchewan and Alaska (Scotter 1964, Swanson et al. 1985). Ahti (1959) similarly found that C. mitis will appear on bare soil within 30-50 years, whereas $C$. stellaris appears after 50-80 years in Newfoundland and 25 years in northern Ontario (Yarranton 1975). For comparison, Crittenden (2000) has reported that $200 \mathrm{~g}$ of crushed thalli of $C$. rangiferina and C. stellaris formed luxurious mats 27 years after being transplanted to sites in northern Finland. Scotter (1964) and Swanson et al. (1985) suggest that lichens are particularly susceptible to fire and will readily burn, the exception to this being moist forest patches. Scotter (1964) noted that fire appears to have a more destructive influence on lichen compared to other plants because of the slow growth rate.

In response to the 2014 Mesilinka wildfire, Tsay Keh Dene Nation initiated the northern mountain caribou post fire habitat restoration project. The project area is near Chase Provincial Park along the Mesilinka River west of the Williston Reservoir (Fig. 1).We assume that because terrestrial lichen had thrived in the caribou winter range areas burned by the wildfire, transplanted lichens should also be able to establish and grow in these areas. Project collaboration expanded to include Chu Cho Environmental, a First Nationowned culturally based environmental consulting company based in Tsay Keh Dene British Columbia, and the British Columbia Ministry of Forests, Lands and Natural Resource Operations and Rural Development. Following an extensive literature review on terrestrial lichen restoration, consultation with a professional Lichenologist, Dr. Troy McMullin, and securing funds from the Fish and Wildlife Compensation Program and the Society for Ecosystem Restoration in North Central British Columbia, this lichen transplant project was carried out.

The objectives of the project were to: 1) accelerate the return of terrestrial lichen winter forage in the area that was burned by the Mesilinka wildfire by transplanting terrestrial lichen fragments and mats; 2) evaluate varying techniques for the transplanting of terrestrial lichen within a post wildfire forest environment; and, 3) inform forest managers, restoration practitioners and academics on the feasibility of, and methods for transplanting terrestrial lichen within a post wildfire forest environment.

\section{Methods}

Lichen collection

As identified by Duncan (2015), a large lichen propagule source is required to supply enough lichen propagules for a restoration project. The following considerations must be carefully weighed when selecting a location to harvest native terrestrial lichen propagules:

\section{Where to collect?}

Duncan (2015) suggests approved disturbance footprints, such as a mine or future reservoir, as candidate sites for collection. Additional considerations should be made to avoid collecting within known habitat for woodland caribou, and absolutely no collection should be considered within critical habitat. Roadsides outside of known caribou habitat, or areas where snow depth limits the forage availability, also have high potential for collection.

\section{How much to collect?}

Kauppi (1979) recommends that no more than $20 \%$ of lichen cover should be removed from an area at one time, and that sites should be picked at 5-6 intervals (units not specified). Both Kauppi (1979) and Duncan (2015) have 


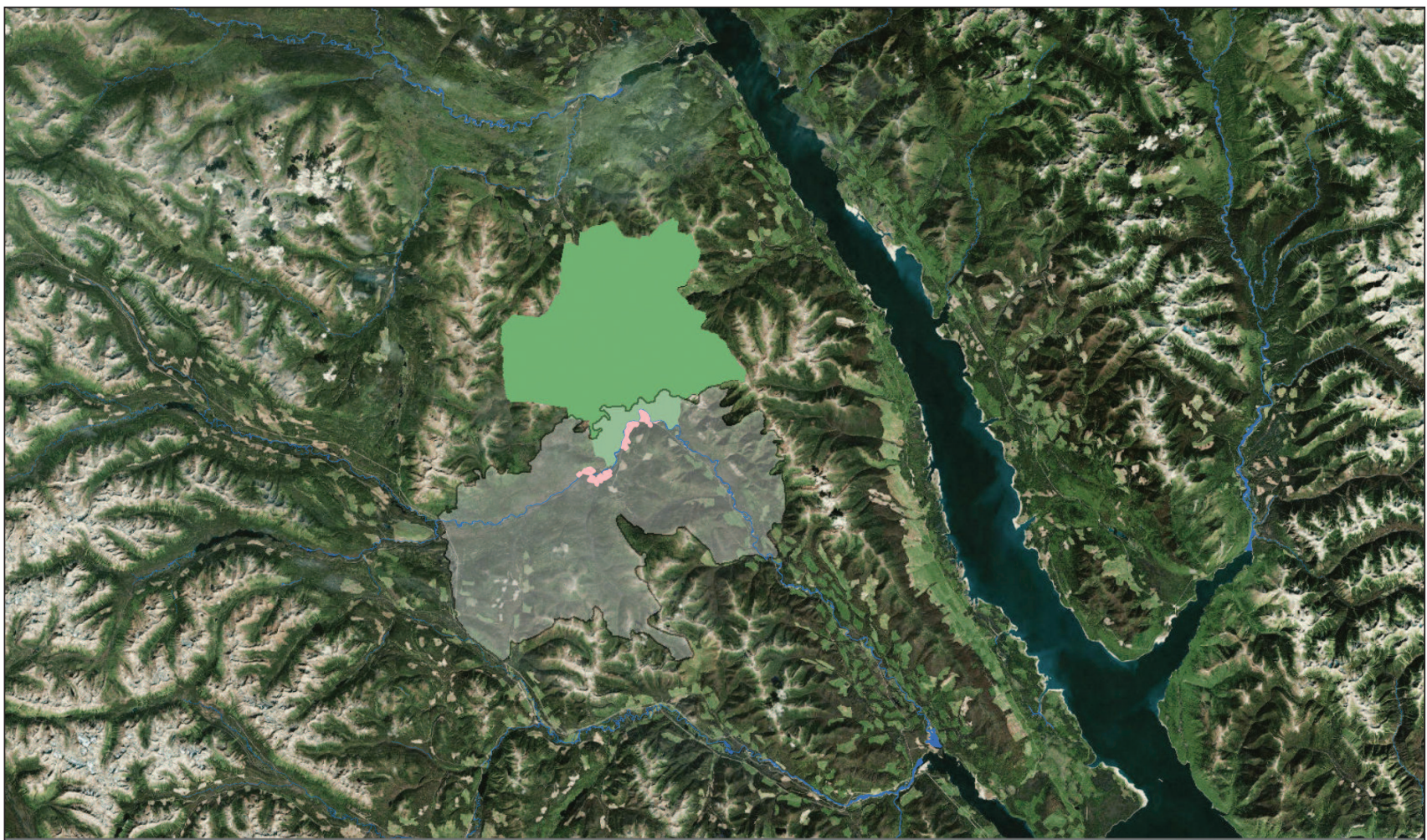

Northern Mountain Caribou Post Fire Habitat Restoration Program
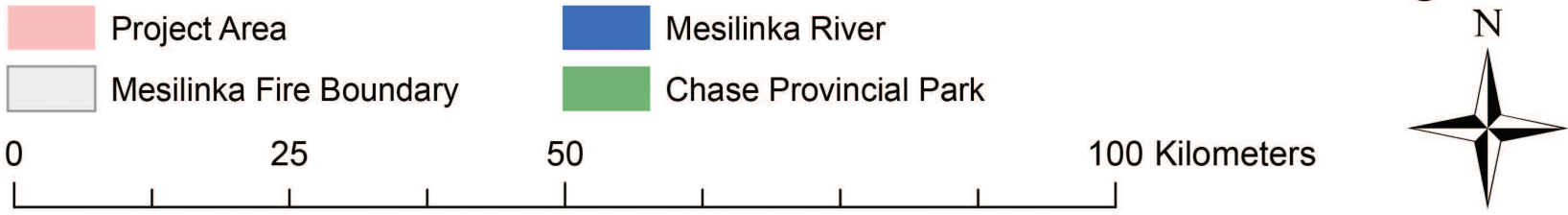

Fig. 1. Research site of the Northern Mountain Caribou Post-Fire Habitat Restoration Project.

recommended that sustainable harvests of terrestrial lichen must be determined and based on reliable research. There is a critical need for more information on what represents a sustainable harvest, as Kauppi (1979) appears to provide an anecdotally based recommendation. This is especially necessary in cases when suitable collection areas can only be identified within caribou range. Based on previous studies, spreading lichen propagules throughout the transplant area could expedite the recovery of terrestrial lichen (Roturier et al. 2007, Roturier and Bergsten 2009, Duncan 2011).

\section{How to store lichen?}

Maintaining viability and preventing decay are two of the main concerns with storing lichen for extended periods of time. Storage in cool, dark and dry conditions is recommended and can preserve collected lichen viability for up to two years (Duncan 2015). In addition to keeping lichen in a low light storage area, allowing the lichen to desiccate may extend the period that it can be stored (Duncan 2011). For short duration projects ( $<5$ days between collection and transplanting), we recommend that the lichen is stored in the collection container and inspected daily for signs of rot. If the lichen is to be stored for a longer period of time, or shows signs of rot while stored, we recommend that the lichen is dried and handled in a manner that reduces fragmentation.

4. Are there community risks to transporting species?

Genetic diversity of lichen in the boreal forest is thought to be relatively low due to asexual reproduction being a major strategy for colony expansion (Kotelko et al. 2008). As such, the possibility for having a negative impact on the genetics of lichen population structure is probably low. To reduce any potential for risk arising from introducing geographic variation, lichens should be collected as close to the transplanting site as possible.

A location for lichen collection was determined for this project through biogeoclimatic zone and terrestrial ecosystem mapping to locate nutrient-poor xeric stands outside of caribou herd areas. These stands are known to have a high potential for terrestrial lichen and are not used by caribou. Consultation with local FLNRORD Biologist (pers. comm. Joanne Vinnedge, British Columbia Lands and Natural Resource 


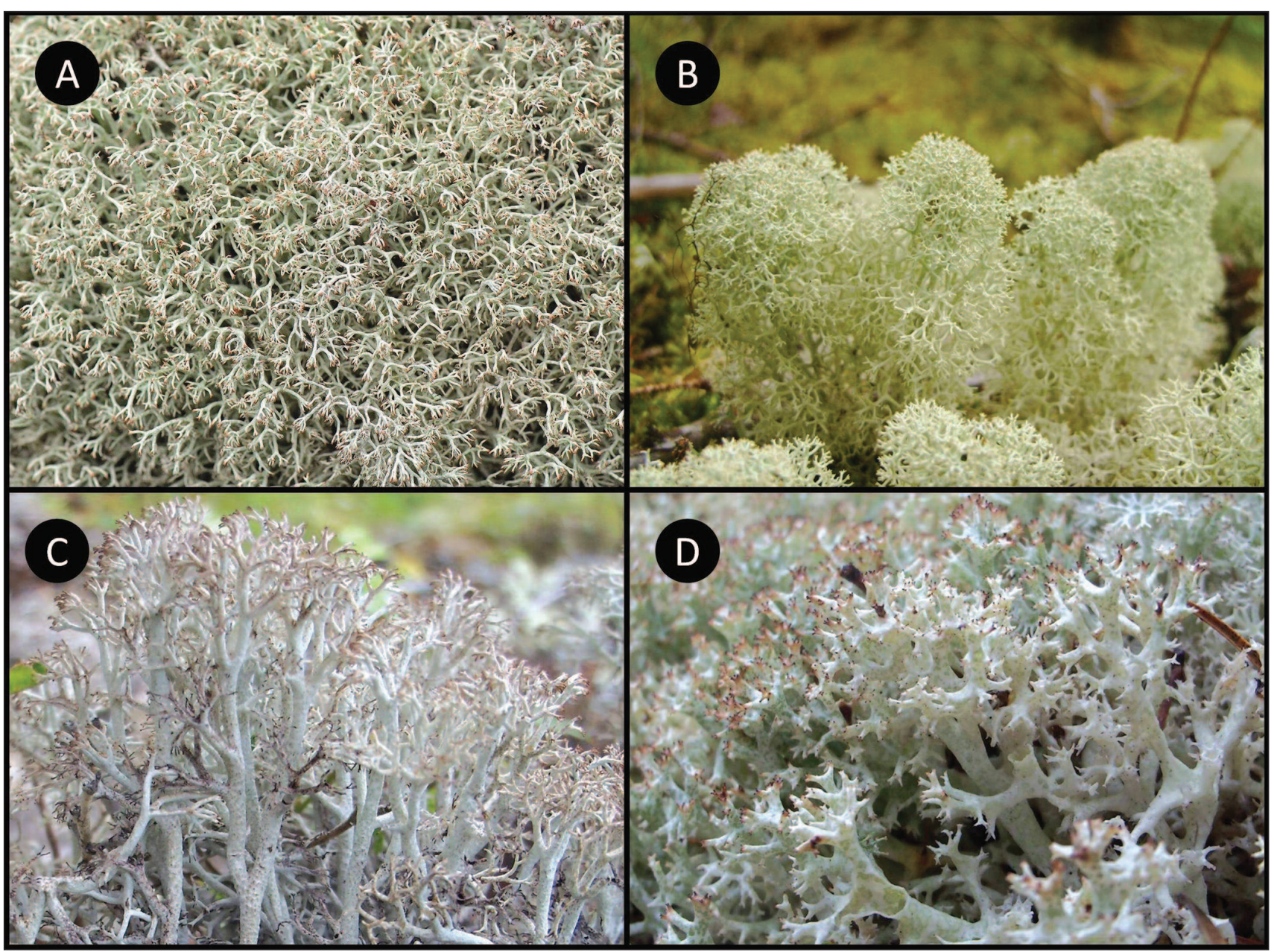

Fig. 2. Species transplanted as part of this project: A) Cladonia mitis, B) C. stellaris, C) C. stygia, and D) C. uncialis.

Operations and Rural Development, June 2016) was also used to confirm the suitability of our candidate sites for lichen collection. The collection area is an even-aged pine forest (Pinus contorta var. latifolia Engelmann) in the moist cool sub boreal spruce biogeoclimatic zone. The collection area is $<200 \mathrm{~km}$ from the study area, and designated to be harvested.

All lichen material was collected by hand for this project, although rakes could be used in areas of high lichen abundance. Cladonia mitis, C. stellaris, C. stygia and C. uncialis (Fig. 2) were identified as candidates for collection based on their importance to woodland caribou winter diets (Environment Canada 2012, Newmaster et al. 2013, B.C. Conservation Data Centre 2016a), and the abundance of these species in the project area. Technicians used the dichotomous keys available in Brodo et al. (2001) and McMullin et al. (2011) to identify species, and collected C. mitis, C. stygia and C. uncialis. Mats were targeted during collection, with an emphasis on collecting a continuous area approximately the size of an outstretched hand. Based on the recommendation in Kauppi (1979), no more than $20 \%$ of the lichen in an area was collected. Technicians used 159-litre Husky contractor clean-up bags to store the lichen. On average, it took 30 minutes to fill each bag with approximately "100 litres" of terrestrial lichen. This was from an area of high lichen cover (25\%) that dis- played large and luxurious mats. In 2015, the same technicians collected lichens from a recent cut block ( $<5$ years). This took approximately 90 minutes to collect "100 litres" of terrestrial lichen mats and fragments. Terrestrial lichen cover was low (5\%), and few mats were present at this site.

We find that dried and desiccated lichen will quickly break into small fragments when stored and transported. This reduces the size and quantity of large mats. If large mats are desired during planting, we recommend that the lichen is collected under moist conditions and then dried. These moist conditions are more common following precipitation or when the lichen is growing under an established tree canopy. When collecting in areas of a recent clear cut or where a canopy is otherwise not present, close monitoring of the lichen moisture levels will inform timing of collection. Kauppi (1979) has suggested that C. stellaris can be collected whenever the ground is free of snow.

\section{Storage}

All collected material was transported to the field in contractor garbage bags. The bags were stored in the shade of the tree canopy for 2-5 days, and were inspected daily for signs of molding. Molding was shown to be a problem with stored lichens (Duncan 2011). The lichens in this project were col- 


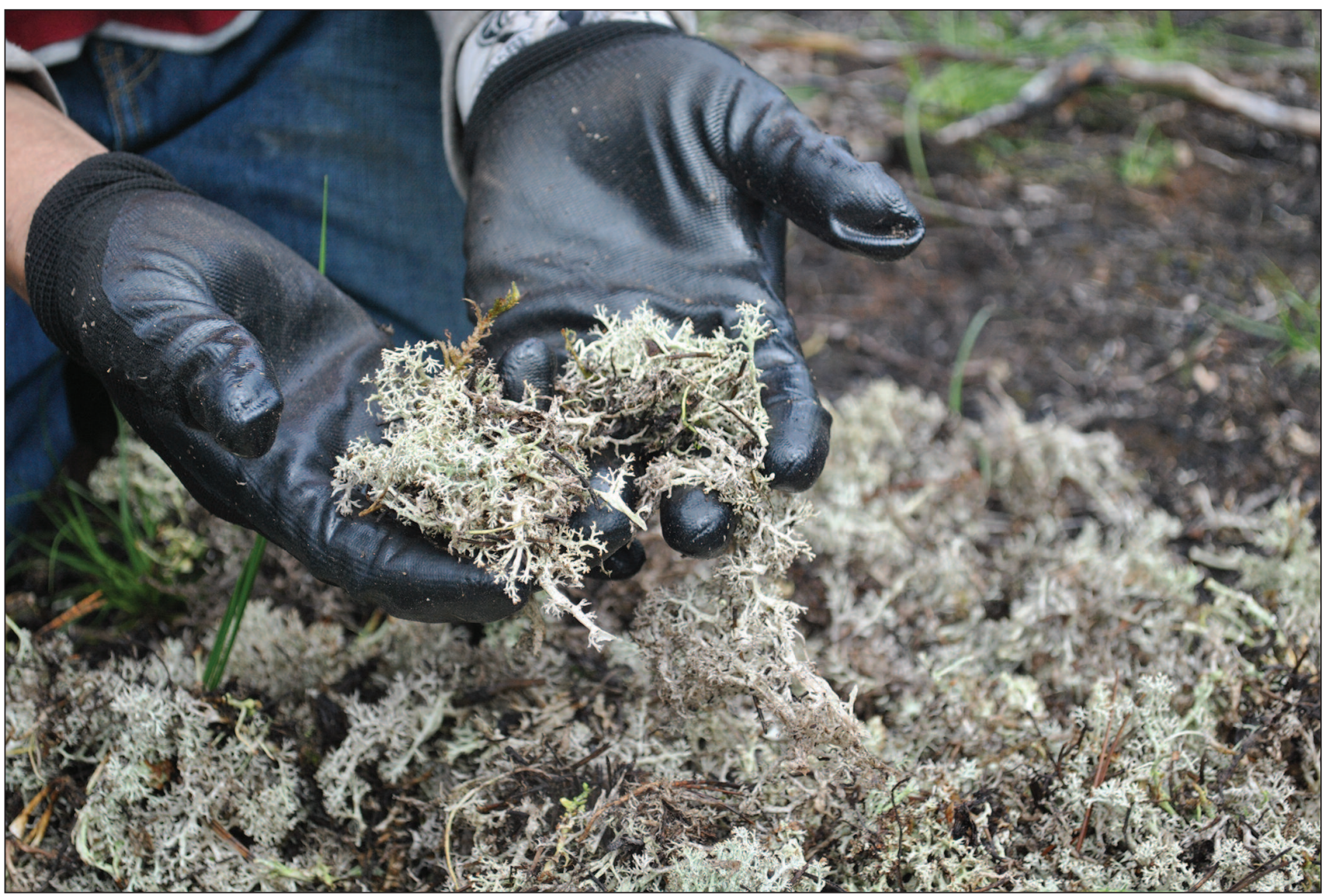

Fig. 3. Example of a field technician shredding the lichen into fragments.

lected when moist, and water droplets formed immediately on the interior of the bags. If molding or rot was suspected, our team was prepared to air dry the lichens and discard rotting material. Due to the short duration between lichen collection and transplanting, molding was not an issue during our project.

\section{Transplanting}

Large intact mats of terrestrial lichen thrived in the coarse, well-drained, nutrient and herb-poor areas prior to the wildfire. Based on this knowledge, our team made the assumption that transplanted lichens could survive and grow on substrates where lichen had been burned (Ahti 1959, Brodo et al. 2001, McMullin et al. 2011). However, burn intensity was not consistent within the fire boundary as fire skips and areas of partial burns with lichen patches were identified. Our team avoided those areas and used the following criteria to select sites where lichen would be transplanted:

1. Knowledge of the local topography and potential access points.

2. Coarse, well-drained soil.

3. $>50 \mathrm{~m}$ from a wetland or riparian habitat.

4. Avoid partially burned spruce or pine stands.

5. Avoid the toes of slopes (receiving areas), depressions, and areas where rainwater is expected to flow and pool in higher volume.

6. Slope angle $<10^{\circ}$.
7. $>50 \mathrm{~m}$ from forest roadways

8. $>50 \mathrm{~m}$ from remnant terrestrial lichen community.

All lichen fragments and mats were distributed by hand. It is possible that a leaf blower (Krekula 2007 in Duncan 2015), helicopter (Enns 1998) or hydro-mulcher could be used to more efficiently distribute lichen fragments. Our project team chose to disperse the lichen by hand as this allowed us to more easily control the volume of lichen applied, and therefore evaluate the benefits of transplanting lichen mats compared to fragments in the future. Due to the uncertainties surrounding the best techniques for establishing terrestrial lichen communities, this project incorporated an experimental design so that differences between treatments can be evaluated and best practices can be recommended. Four treatments were applied as part of this study with 20 replicates of $100 \mathrm{~m}^{2}$ for each treatment:

i) Control (no lichen),

ii) Lichen mats only $(100 \mathrm{~L})$,

iii) Lichen mats $(50 \mathrm{~L})$ and fragments $(50 \mathrm{~L})$, and

iv) Lichen fragments only $(100 \mathrm{~L})$.

Lichen fragments were shredded into 2- to $7-\mathrm{cm}$ pieces (Fig. 3) by hand and broadcasted evenly throughout the 100 $\mathrm{m}^{2}$ plot. The lichen was broadcast in a method similar to spreading grass seed or fertilizer by hand. Technicians did not orientate individual lichen stems, but worked to ensure that the fragments came into contact with the soil. For example, if fragments came to rest on rocks, stumps or logs, the stems 


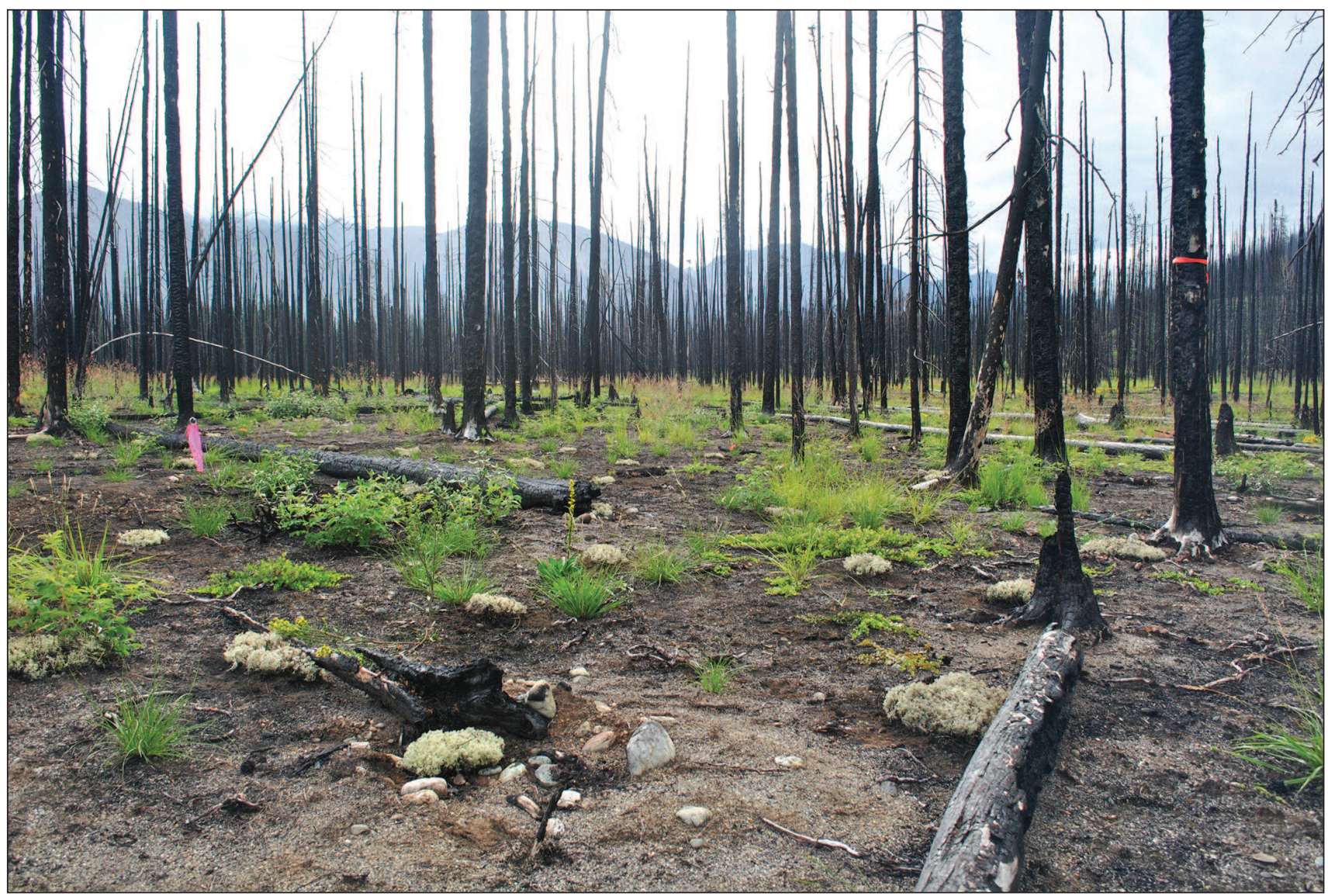

Fig. 4. Example of the mat treatment.

were brushed onto the ground. With the mat treatment, technicians used intact pieces of lichen (the size of a clenched fist to an outstretched palm) and placed these lichen with the basal area oriented downwards. The approach was similar to that of tree planting, as technicians worked to obstacle mats around logs, stumps and other immovable objects (Fig. 4), and the substrate was pulled around the edge of the mat. This approach is based on the results of Enns (1998) who noted that transplanted lichen colony survival was "associated with shelter from large logs (coarse woody debris)." This technique is best described as 'gardening,' as each mat was planted, whereas the fragments were broadcast. The fragment treatment was more efficient to distribute. Two technicians took < 5 minutes to distribute fragments over $100 \mathrm{~m}^{2}$, whereas the mat treatment took two technicians 10-15 minutes to evenly distribute over $100 \mathrm{~m}^{2}$. With little instruction, all technicians and volunteers were able to obstacle mats and distribute fragments with ease. While vehicles were used to transport the lichen along forest roads, reducing the volume of lichen within each bag made traversing to the study area safer for technicians.

Approximately 6000 litres of terrestrial lichen were transplanted over $6000 \mathrm{~m}^{2}$ within the Mesilinka fire boundary that is designated as Caribou Ungulate Winter Range. Twenty replicates of four treatment variations were established, for a total of 80 experimental units that are 100 $\mathrm{m}^{2}$ each. Further monitoring will allow our team to determine the best treatment technique for restoring terrestrial lichen communities. The control plots will also allow our team to evaluate the rate of natural lichen succession within the wildfire boundary, and evaluate our assumption that terrestrial lichen establishment in the area is dispersal limited.

Cladonia mitis represented $56 \%$ of all lichen transplanted, whereas C. uncialis was $26 \%$, C. stygia $17 \%$ and C. stellaris $0.001 \%$ (Fig. 2). Lichen percent cover by treatment and species is provided in Table 1. Control plots have an average terrestrial lichen percent cover of $0 \%$. Whereas average ocular percent cover of islands receiving the mat treatment was $2.01 \%$, compared with $3.78 \%$ cover in the hybrid mat and fragment treatments, and $4.78 \%$ cover in fragment only treatments.

Table 1. Cladonia sub-genus Cladina and Cladonia uncialis percent cover by species within transplanted islands

\begin{tabular}{lccccc} 
Treatment & $\begin{array}{c}\text { Cladonia } \\
\text { mitis }\end{array}$ & $\begin{array}{c}\text { Cladonia } \\
\text { stellaris }\end{array}$ & $\begin{array}{c}\text { Cladonia } \\
\text { stygia }\end{array}$ & $\begin{array}{c}\text { Cladonia } \\
\text { uncialis }\end{array}$ & Total \\
\hline Mats Only & $1.27 \%$ & $0.01 \%$ & $0.38 \%$ & $0.35 \%$ & $2.01 \%$ \\
Control & $0.00 \%$ & $0.00 \%$ & $0.00 \%$ & $0.00 \%$ & $0.00 \%$ \\
Mats and Fragments & $2.62 \%$ & $0.00 \%$ & $0.63 \%$ & $2.27 \%$ & $3.78 \%$ \\
Fragments Only & $3.05 \%$ & $0.01 \%$ & $1.03 \%$ & $0.65 \%$ & $4.78 \%$ \\
\hline
\end{tabular}




\section{Future Recommendations}

The literature indicates that terrestrial lichen fragment and mat transplants can be used to establish terrestrial lichen communities (Roturier et al. 2007, Roturier and Bergsten 2009, Duncan 2011, 2015). However, it remains unclear which technique is best for restoring terrestrial lichen. In order to evaluate the best method for restoring terrestrial lichen within a post wildfire forest environment, a plan for long-term monitoring of this project has been implemented. These data will allow our team to track and compare lichen establishment and growth between treatments, but also evaluate the ecological trajectory of the vascular plant community within our permanent plots.

The environmental and ecological issues that are impacting the Chase herd are not unique. The results of this program will inform lichen transplanting projects in other caribou ranges where suitable conditions exist. The dissemination of information on practical techniques for restoring woodland caribou habitat through publications, knowledge-sharing, and collaboration will play an important role in woodland caribou recovery across Canada. The techniques described in this article can be added to the toolbox of any restoration practitioner or academic looking to become engaged in the recovery of woodland caribou and in meeting the goals of Canada's boreal caribou recovery plan.

\section{Acknowledgements}

We thank the Society for Ecosystem Restoration in northcentral British Columbia (SERNbc) for the financial support for this publication, and for ongoing extension work related to the Northern Mountain Caribou Post Fire Habitat Restoration Program. Ongoing monitoring and extension is a critical component of all restoration programs, and we are thankful for SERNbc's recognition and support of this. We also gratefully acknowledge the financial support of the Fish and Wildlife Compensation Program for its contribution to the Northern Mountain Caribou Post Fire Habitat Restoration. www.fwcp.ca. The FWCP is a partnership between BC Hydro, the Province of B.C., Fisheries and Oceans Canada, First Nations and public stakeholders to conserve and enhance fish and wildlife impacted by the construction of $\mathrm{BC}$ Hydro dams.

The project team would also like to thank Dr. Darwyn Coxson and Trevor Goward for their advice in establishing initial trials in summer 2015, and two anonymous reviewers for their helpful comments on the manuscript. Volunteers from Tsay Keh Dene Nation were integral in carrying out this project, as was Tsay Keh Dene Lands, Resources and Treaty Operation which provided in-kind support in the form of technicians, field accommodations and the invaluable advice for enhancing community engagement in this project. This project would not have been possible without the support and leadership of the Tsay Keh Dene Nation.

\section{References}

Ahti, T. 1959. Studies on the caribou lichen stands of Newfoundland. Ann. Bot. Soc. Zool. Bot. Fenn. 'Vanamo'. 30: 1-44.

Ahti, T. 1961. Open boreal woodland subzone and its relation to reindeer husbandry. Archivum Soc. Zool. Bot. Fenn. 'Vanamo.' 16: 91-93.
B.C. Conservation Data Centre. 2016a. Species Summary: Rangifer tarandus pop. 15. B.C. Min. Environ. http://a100.gov.bc.ca/ pub/eswp/ [accessed 15 December 2016].

B.C. Conservation Data Centre. 2016b. Species Summary: Rangifer tarandus pop. 1. B.C. Min. Environ. http://a100.gov.bc.ca/pub/eswp/ [accessed 13 December 2016].

Boreal Caribou Aboriginal Traditional Knowledge (ATK). Reports (2010-2011) Compiled June 2011. Ottawa: Environment Canada. https://www.registrelepsararegistry.gc.ca/default.asp?lang= En\&n=06D443C4-1 [accessed 20 January 2017].

Brodo, I.M., S.D. Sharnoff and S. Sharnoff. 2001. Lichen of North America. New Haven and London: Yale University Press.

Campeau, S. 2013. Establishing alvar mosses on quarry floors: A necessary step in the restoration of quarries to alvars. Final Report to the Ontario Aggregate Resources Corporation (TOARC). Bryophyta Technologies inc., Lambton, Quebec.

Carroll, S.B. and L.C. Bliss. 1982. Jack pine-lichen woodland on sandy soils in northern Saskatchewan and northeastern Alberta. Can. J. Bot. 60:2270-2282.

COSEWIC. 2011. Designatable Units for Caribou (Rangifer taran$d u s$ ) in Canada. Committee on the Status of Endangered Wildlife in Canada. Ottawa. 88 p.

COSEWIC. 2014a. COSEWIC assessment and status report on the Caribou Rangifer tarandus, Northern Mountain population, Central Mountain population and Southern Mountain population in Canada. Committee on the Status of Endangered Wildlife in Canada. Ottawa.

COSEWIC. 2014b. COSEWIC assessment and status report on the Caribou Rangifer tarandus, Newfoundland population, AtlanticGaspésie population and Boreal population in Canada. Committee on the Status of Endangered Wildlife in Canada. Ottawa.

Cichowski, D.1993. Seasonal movements, habitat use and winter feeding ecology of woodland caribou in west-central British Columbia. Land Management Report. no. 79.

Cichowski, D. and S. Haeussler. 2013 The Response of Caribou Terrestrial Forage Lichens to Forest Harvesting and Mountain Pine Beetles in the East Ootsa and Entiako Areas: Ann. Rept. - 2012/13 Year 11. Smithers, BC.

Cichowski, D., P. Williston and S. Haeussler. 2008. The Response of Caribou Terrestrial Forage Lichens to Mountain Pine Beetles and Forest Harvesting in the East Ootsa and Entiako Areas: Annual Report - 2007/08 - Year 7. A report to Morice-Lakes Innovative Forest Practices Agreement, Prince George, B.C., the Bulkley Valley Centre for Natural ResourcesResearch and Management, Smithers, B.C., and Ministry of Environment, Prince George, B.C.

Crittenden, P.D. 2000. Aspects of the ecology of mat-forming lichens. Rangifer. 20:127-139.

Denryter, K.A., R.C. Cook, J.G. Cook and K.L. Parker. 2017. Straight from the caribou's (Rangifer tarandus) mouth: Detailed observations of tame caribou reveal new insights into summerautumn diets. Can. J. Zool. 95: 81-94.

Duncan, S. 2011. Reindeer Lichen Transplant Feasibility for Reclamation of Lichen Ecosites on Alberta's Athabasca Oil Sand Mines. M.Sc. thesis, Environmental Studies, University of Victoria, Victoria, BC.

Duncan, S.J. 2015. Woodland caribou alpine range restoration: An application for lichen transplants. Ecol. Restor. 33: 22-29.

Dunford, J.S., P.D. McLoughlin, F. Dalerum and S. Boutin. 2006. Lichen abundance in the peatlands of northern Alberta: Implications for boreal caribou. Ecosci. 13: 469-474.

Dzus, E. 2001. Status of the Woodland Caribou (Rangifer tarandus caribou) in Alberta. Alberta Environment, Fisheries and Wildlife Management Division, and Alberta Conservation Association, Wildlife Status Report No. 30, Edmonton, AB. 
Enns, K. 1998. Forage Lichen Enhancement in the Itcha - Ilgachuz Caribou Range. British Columbia Ministry of Environment Lands and Parks, Fish and Wildlife Branch. Williams Lake, B.C.

Environment Canada. 2012. Recovery Strategy for the Woodland Caribou (Rangifer tarandus caribou), Boreal population, in Canada. Species at Risk Act Recovery Strategy Series. Environment Canada, Ottawa.

Environment Canada. 2014. Recovery Strategy for the Woodland Caribou, Southern Mountain population (Rangifer tarandus caribou) in Canada. Species at Risk Act Recovery Strategy Series. Environment Canada, Ottawa. viii +103 p.

Festa-Bianchet, M., J.C. Ray, S. Boutin, S.D. Cote and A. Gunn. 2011. Conservation of caribou (Rangifer tarandus) in Canada: A uncertain future. Can. J. Zool. 89: 419-434.

Government of Alberta. 2016. ${ }^{\star}$ Draft $^{\star}$ Little Smokey and a La Peche Caribou Range Plan. June 2, 2016

Goward, T. 2000. Fire, terrestrial lichens, and the Itcha-Ilgachuz caribou. L. M. Darling, editor. 2000. Proceedings of a Conference on the Biology and Management of Species and Habitats at Risk, Kamloops, B.C., 15-19 Feb., 1999. Volume Two. B.C. Ministry of Environment, Lands and Parks, Victoria, B.C. and University College of the Cariboo, Kamloops, B.C.

Heinken, T. 1999. Dispersal patterns of terricolous lichen by thallus fragments. Lichenologist. 31:603-612.

Hugron, S., M. Poulin and L. Rochefort. 2013. Organic matter amendment enhances establishment of reintroduced bryophytes and lichens in borrow pits located in boreal forest highlands. Boreal Envir. Res. 18: 317-328.

James, A.R.C. and A.K. Stuart-Smith. 2000. Distribution of caribou and wolves in relation to linear features. J. Wildlife Manage. 64:154-159.

Kauppi, M. 1979. The exploitation of Cladonia stellaris in Finland. Lichenologist 11:85-89.

Kotelko, R., M. Doering and M.D. Piercey-Normore. 2008. Species diversity and genetic variation of terrestrial lichens and bryophytes in a boreal jack pine forest of central Canada. The Bryologist. 111: 594-606.

Maikawa, E. and K.A. Kershaw. 1976. Studies on lichen dominated systems XIX. The postfire recovery sequence of black sprucelichen woodland in the Abitan Lake region. Can. J. Bot. 54: 2674-2687.

McLoughlin, P.D., E. Dzus, B. Wynes and S. Boutin. 2003. Declines in populations of woodland caribou. J. Wildlife Manage. 67: 755-761.

McMullin, R.T., I.D. Thompson, B.W. Lacey and S.G. Newmaster. 2011. Estimating the biomass of woodland caribou forage lichens. Can. J. For. Res. 41: 1961-1969.

Morneau, C. and S. Payette. 1989. Postfire lichen-spruce woodland recovery at the limit of the boreal forest in northern Quebec. Can. J. Bot. 67: 2770-2782.

Nash, T.H. 2008. Lichen Biology. $2^{\text {nd }}$ edition. Cambridge University Press, Cambridge.

Newmaster, S.G., I.D. Thompson, R.A.D. Steeves, A.R. Rodgers, A.J. Fazeka, J.R. Maloles, R.T. McMullin and J.M. Fryxell. 2013. Examination of two new technologies to assess the diet of woodland caribou: video recorders attached to collars and DNA barcoding. Can. J. For. Res. 43: 897-900.
Pigeon, K.E., M. Anderson, D. MacNearney, J. Cranston, G. Stenhouse and L. Finnegan. 2016. Toward the restoration of caribou habitat: Understanding factors associated with human motorized use of legacy seismic lines. Environ. Manage. 58: 821-832.

Rapai, S.B., R.T. McMullin and S.G. Newmaster. 2016. Restoring Terrestrial Lichen Communities on the Detour Lake Mine Property. Progress Report December 2016.

Roturier, S. and U. Bergsten. 2009. Establishment of Cladonia stellaris after artificial dispersal in an unfenced forest in northern Sweden. Rangifer. 29: 39-49.

Roturier, S., S. Backlund, M. Sunden and U. Bergsten. 2007. Influence of ground substrate on establishment of reindeer lichen after artificial dispersal. Silva Fenn. 41: 269-280.

Seip, D.R. 1992. Factors limiting woodland caribou populations and their interrelationships with wolves and moose in southeastern British Columbia. Can. J. Zool. 70: 14941503.

Scotter, G.W. 1964. Effects of Forest Fires on the Winter Range of Barren-Ground Caribou in Northern Saskatchewan. Canadian Wildlife Service. Wlidlife Management Bulletin, Series 1, No. 18.

Schaefer, J.A., A.M Veitch, F.H. Harrington, W.K. Brown, J.B. Theberge and S.N. Luttich. 1999. Demography of decline of the Red Wine Mountain caribou herd. J. Wildlife Manage. 63: 580-587. Swanson, J.D., M. Schuman and P.C. Scorup. 1985. Range Survey of the Seward Peninsula Reindeer Ranges, Alaska. Prepared by United States Department of Agriculture Soil Conservation Service. Thomas, D.C., S.J. Barry and G. Alaie. 1996. Fire - Caribou-winter range relationships in northern Canada. Rangifer. 16: 57-67.

Thompson, I.D., P.A. Wiebe, E. Mallon, A.R. Rodgers, J.M. Fryxell, J.A. Baker and D. Reid. 2015. Factors influencing the seasonal diet selection by woodland caribou (Rangifer tarandus tarandus) in boreal forests in Ontario. Can. J. Zool. 93: 87-98.

Vors, L.S., J.A. Schaefer, B.A. Pond, A.R. Rogers, B.R. Patterson. 2007. Woodland caribou extirpation and anthropogenic landscape disturbance in Ontario. J. Wildlife Manage. 71:1249-1256.

Webb, E.T. 1998. Survival, persistence, and regeneration of the reindeer lichens, Cladonia stellaris, C. rangiferina, and C. mitis following clearcut logging and forest fire in northwestern Ontario. Rangifer, Special Issue 10: 41-47.

Williston, P. and D. Cichowski. 2004. The Response of Caribou Terrestrial Forage Lichens to Forest Harvesting and Mountain Pine Beetles in the East Ootsa and Entiako Areas: Annu. Rep. - 2003/04 Year 3. A report to West Fraser Sawmills, Fraser Lake BC., and Min. Water, Land and Air Prot., Smithers, B.C.

Wittmer, H.U., R.N.M. Ahrens and B.N. McLellan. 2010. Viability of mountain caribou in British Columbia, Canada: Effects of habitat change and population density. Biol. Conserv. 143: 86- 93.

Yarranton, G.A. 1975. Population growth in Cladonia stellaris (Opiz.) Pouz. and Vezda. New Phytol. 75: 99-110. 